УДК 004.65:001.92:004.77

Іванова Світлана Миколаївна

завідувач відділу комп'ютерно орієнтованих систем навчання і досліджень

Інститут інформаційних технологій і засобів навчання НАПН України, м. Київ, Україна

iv-svetlana@yandex.ru

\title{
ПРОЕКТУВАННЯ ІНФОРМАЦІЙНО-КОМУНІКАЦІЙНОЇ ПІДТРИМКИ НАУКОВОЇ ДІЯЛЬНОСТІ НА БАЗІ СИСТЕМИ ЕPRINTS
}

\begin{abstract}
Анотація. Стаття присвячена проблемі проектування моделі інформаційно-комунікаційної підтримки наукової діяльності для забезпечення ефективного оприлюднення, розповсюдження та використання продукції наукових установ. Уточнено поняття «інформаційно-комунікаційна підтримка наукової діяльності» та запропонована структура інформаційно-комунікаційної підтримки. Створена модель інформаційно-комунікаційної підтримки наукової діяльності на базі системи EPrints. В межах моделі виокремлені такі компоненти як ціннісно-цільовий, змістовний, організаційно-технологічний, результативний. Запропоновано припущення, що модель інформаційно-комунікаційної підтримки наукової діяльності на базі системи EPrints систематизує роботу наукових працівників в постійно зростаючому обсязі наукової продукції та підтримує мотивацію наукових працівників до підвищення іiї якості.
\end{abstract}

Ключові слова: інформаційно-комунікаційна підтримка наукової діяльності; система EPrints; наукова продукція.

\section{ВСТУП}

В інформаційному суспільстві визначальним чинником стають знання. Відмінною рисою розвитку людства у XXI столітті є їх зберігання, перетворення, передавання і використання за допомогою інформаційно-комунікаційних технологій (IКТ). Одним із важливих завдань суспільства при цьому є продукування нових знань та забезпечення науки, культури та освіти належною інформаційно-комунікаційною підтримкою (IКпідтримка).

Активізація наукової діяльності, результатом якої $\epsilon$ основний продукт інформаційного суспільства - нові знання, може бути здійснена завдяки наявності необхідних ІК-підтримки та інформаційно-комунікаційної компетентності (IКкомпетентності) наукових працівників. На законодавчому рівні цей процес відзначено в Законах України «Про затвердження Національної стратегії розвитку інформаційного суспільства в Україні на 2006-2015 роки», «Про наукову i науково-технічну діяльність», «Про інноваційну діяльність», «Про Концепцію Національної програми інформатизації», а також у Державній програмі «Інформаційні та комунікаційні технології в освіті і науці» на 2011 - 2013 рр.

Одним із найбільш перспективних способів інформаційно-комунікаційної підтримки наукової діяльності є створення електронних бібліотек (ЕБ) як розподілених інформаційних систем, що дозволяють накопичувати, зберігати і використовувати колекції електронних документів, доступних у зручному для наукових працівників вигляді через глобальні мережі передачі даних. Особливість такого роду бібліотек полягає в тому, що певна частина інформаційного фонду після цифрового опрацювання стають вільно доступними.

Суттєву роль відіграють електронні бібліотеки у професійному розвитку науковців, зокрема, у здійсненні ними науково-педагогічних досліджень та обміні досвідом. 
3 огляду на особливе значення ЕБ у професійній діяльності наукових працівників стає актуальним вибір, наукове обгрунтування та практична реалізація програмних систем для створення наукових електронних бібліотек. Їх використання надає можливість, з одного боку, вільного доступу до великої кількості наукового матеріалу, a 3 іншого, професійного розвитку науковців, вдосконалення вмінь та навичок працювати з різними ІКТ для виконання науково-дослідної діяльності.

Постановка проблеми. Аналізу ролі електронних бібліотек для наукових та навчальних закладів присвячені роботи зарубіжних дослідників О. Гарбо, В. Редінг, Е. Макдональд, Т. Браже та ін. Вони зазначали, що у зв'язку з активним зростанням пріоритету знань у сучасному суспільстві, підвищується і значення електронних бібліотек. Окремі аспекти підвищення актуальності електронних ресурсів, каталогів, архівів та ін. розглядають російські науковці О. І. Вісли, О. І. Земськов, О. Г. Фонотов, Ю. С. Хохлов та ін. Серед вітчизняних досліджень слід відмітити роботи Л. Й. Костенко, О. С. Онищенко, Т. П. Павлуші, І. А.Павлуші , О. М. Спіріна.

Проблемі вибору та адаптації програмних систем для створення електронних бібліотек приділяється увага в роботах Н. В. Морзе, О. Г. Кузьмінської, В. А. Резніченко, Г. Ю. Проскудіної, О. М. Овдія, А. Ю. Дорошенко та ін.

Проблема вдосконалення у фахівця вмінь та навичок використовувати IКТ у професійній діяльності розглядається у роботах Н. В. Баловсяк, В. Ю. Бикова, В. П.Вембра, Г. В.Сльнікової, Н. В.Морзе, О. Г.Кузьминської, О. В. Овчарук, Л. Є. Петухової, О. М. Спіріна, Н. В. Сороко, Є. Хвілона, А. В. Хуторського та ін.

Проте, аналіз праць свідчить, що проблема формування ІК-підтримки професійної діяльності наукових працівників залишається недостатньо вивченою.

Метою статті є проектування моделі ІК-підтримки наукової діяльності на базі системи EPrints.

Методи дослідження. Основними методами, що використовувалися в цьому дослідження, є: аналіз ресурсів мережі Інтернет, методичної і спеціальної літератури 3 досліджуваної проблеми, публікацій вітчизняних та зарубіжних учених; основних характеристик IKT, зокрема системи EPrints, що дозволяють автоматизувати процеси збирання, опрацювання та подання статистичних відомостей про результати науковопедагогічних досліджень.

\section{Аналіз останніх досліджень і публікацій.}

Варто зазначити, що впровадження результатів наукової діяльності в галузі педагогічних наук передбачає такі дії як оприлюднення, розповсюдження та використання продукції наукових установ (наукової, науково-виробничої, навчальної, довідкової, електронних ресурсів та ін.) цільовою групою користувачів [8]. Важливим при цьому стає інформаційно-комунікаційна підтримка наукової діяльності, як засіб для адекватного аналізу зазначених дій.

Визначення поняття ІК-підтримка не зустрічається у зазначених вище дослідженнях, тому уточнимо його відповідно до лексичного значення слів, які входять до його складу.

Так, лексичне значення слова «підтримка»- допомога, сприяння [7, 433]. Так, у розумінні «допомога» мається на увазі стрімка дія, та поняття «сприяння» розуміється, як створення умов для виконання певної діяльності, у нашому дослідженні - наукової діяльності у галузі педагогічних наук.

Інформаційно-комунікаційна підтримка наукової діяльності - це допомога та сприяння суб'єктам наукової діяльності в отриманні та розповсюдженні наукового результату з використанням IКТ.

Слід зазначити, що у словнику С. Ожегова [7] термін „проектування” відсутній, але дається тлумачення словам „проект” і „проектувати”, значення яких зводиться до 
побудови, планування чого-небудь. У словнику «Науково-технічний прогрес» поняття «проектування» визначається як «тісно пов’язана 3 наукою та інженерією діяльність щодо створення проекту, що сформувалася в межах діяльності з виготовлення нових виробів, машин і механізмів» [5]. У даному джерелі описано, спочатку виділення 3 цієї діяльності «особливого етапу» (друга половина XIX - початок XX ст.), пов'язаного 3 «конструктивною розробкою ідей і варіантів нового об' єкта», а з часом - «необхідність попередніх досліджень i конструктивних розробок, здійснюваних у площині креслення», призвели до «виокремлення проектування як самостійного виду діяльності». Одним із основних етапів проектування є створення моделі.

Поняття «модель» (від лат. modulus - міра, зразок, норма, пристрій, еталон, макет) у Логічному словнику M.I. Кондакова [4, 360] визначається як штучно створений об'єкт у вигляді схеми, логіко-математичних знакових формул, фізичних конструкції та ін. Важливим при цьому є виокремлення необхідних елементів, що будуть впливати на результативність функціонування створеної моделі. Так, для визначення таких елементів, варто зазначити, що у процесі наукової діяльності можуть використовуватися географічно розподілені наукові ресурси: відкриті програмні системи, бази даних та інші джерела відомостей, соціальні сервіси мережі, мережні ресурси та ін [1].

Розглянемо окремі елементи ІК-підтримки наукової діяльності, зокрема науковопедагогічної, для 3'ясування компонентів моделі зазначеної підтримки. Так, багато дослідників (вітчизняних науковців В. Ю. Биков, Л. А. Карташова, Т. І. Коваль, О. М. Самойленко та ін., зарубіжних вчених В.Скот (Virginia A. Scott), Б.Драшел (Bruce E. Drushel), К. Герман (Kathleen German), Дж.Річ (Justin Reich), Т.Декорд (Thomas Daccord), А.Новембер (Alan November) та ін.) відмічають сервіси, «Веб 2.0» (наприклад, Squidoo, Hubpages, WordPress, Wetpaint, Blogger, Wiki, Scribd, Digg, Weebly та ін.).

Wiki-cuстеми (наприклад, Wikipedia) - гіпертекстові середовища для збирання i структурування письмових відомостей, які характеризуються наступними ознаками: великою кількістю авторів; можливістю багаторазово правити текст засобами самого середовища; можливістю спостерігати за динамікою змін відразу після їх внесення; можливістю розділяти інформаційний ресурс на частини, що мають свою назву; особливу мову розмітки; можливістю враховувати зміни тексту і повернення до попередньої версії документа.

Системи сумісної наукової діяльності декількох співучасників редагування та створення контенту (collaboration editing) (наприклад, GoogleDocs, Spreadsheets, Gliffy (diagrams), GoogleWave), що забезпечують можливість спільного одночасного доступу до документів різних форматів, роботу з ними, обговорення дослідження та ін.

Блоги і мікроблоги (наприклад, Twitter, Blog.com, ЖЖ) - веб-сайт, основний вміст якого - записи, зображення або мультимедіа, що регулярно додаються, для яких характерна можливість одночасного ознайомлення учасників наукової діяльності 3 матеріалом і написання відгуків до записів безпосередньо в електронному середовищі та публічність.

Технології синдикації і нотифікації (RSS - Really Symple Syndication) - сімейство XML-форматів, призначених для опису новин, анонсів статей, змін у блогах та ін.

Вебінари - семінари, що проходять у мережі Інтернет, он-лайн лекції, дистанційні курси, он-лайн презентаці, організовані за допомогою web-технологій.

Соціальні мережі $і$ системи соичільних презентацій (наприклад, Facebook, MySpace, Linkedln; Second Life; Odnoklassniki.ru; Profeo).

Соиіальні закладки (наприклад, Delicious; Bibsonomy, Zeto). 
Сервіси зберігання та відображення мультимедійної інформації (наприклад, YouTube, iTunes; Scribd; Flicker; SlideShare).

Підкасти (наприклад, Podcast people, PodOmatic, PodBean).

Системи ВЕБ-інтеграції і бриколажу (наприклад, Del.icio.us; SkypeMe; PingMe services; Yahoo Pipes), що дозволяють форматувати і змішувати різні формати представлення відомостей та даних і обробляти веб-сторінки.

3 огляду на вищезазначені сервіси та специфіку шляхів впровадження результатів наукової діяльності, нижче, на рисунку 1, представлена структура інформаційнокомунікаційної підтримки наукової діяльності, яка включає такі компоненти як джерела відомостей і даних (ресурси мережі Інтернет, бази даних, наукові спільноти та ін.) та інструменти (соціальні сервіси мережі Інтернет, відкриті програмні системи та ін.) для їх оприлюднення, розповсюдження та використання.

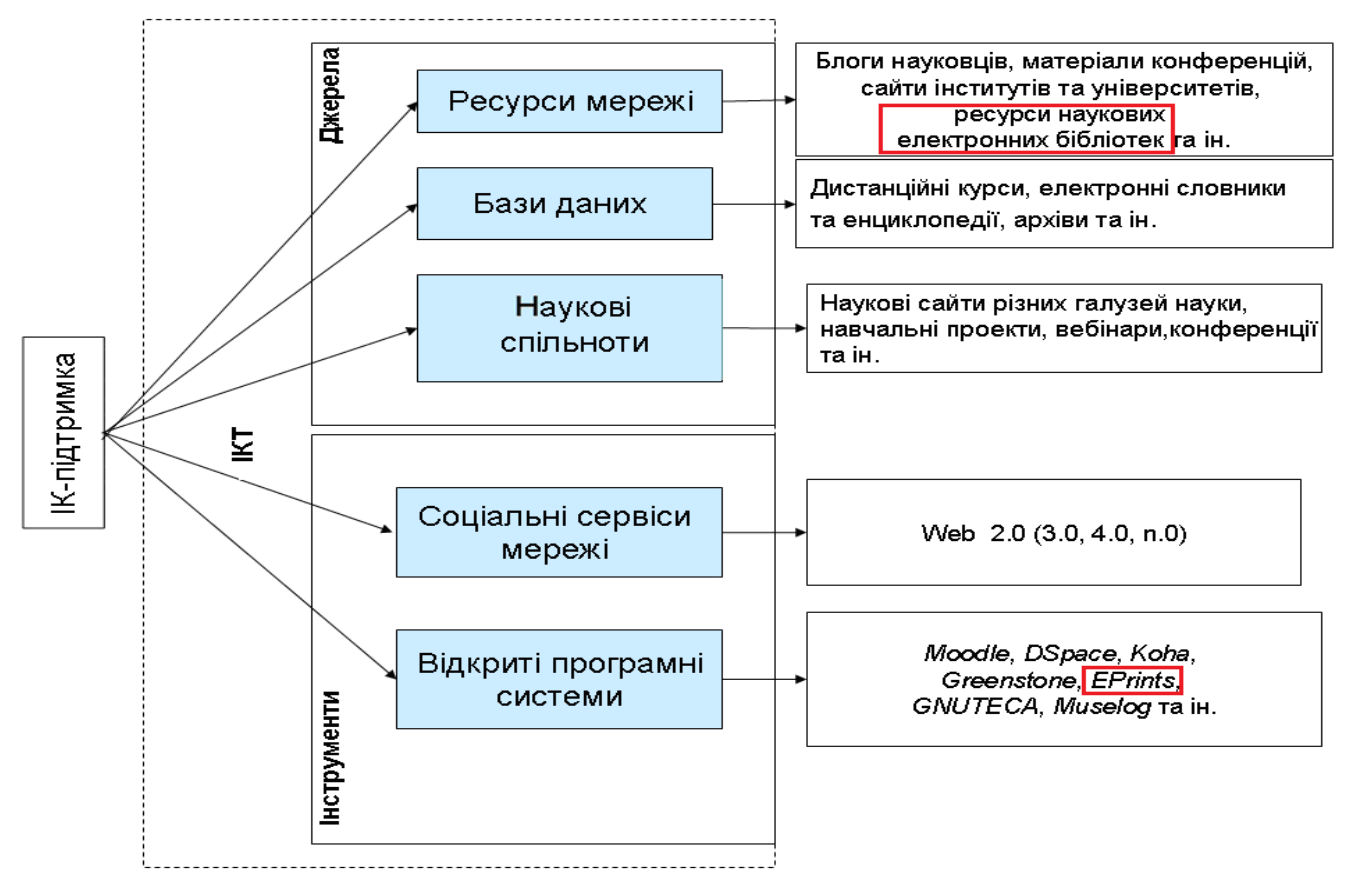

Рис.1. Структура інформачійно-комунікачійної підтримки наукової діяльності

Одним із найбільш затребуваних елементів ІК-підтримки наукової діяльності стали електронні бібліотеки (Digital library) [11]. Їх особливість полягає в тому, що певна частина інформаційних ресурсів після цифрової обробки стає доступною для великої кількості користувачів через мережу.

Суттєвою проблемою при цьому постає вибір програмного забезпечення для створення наукових електронних бібліотек (НЕБ), що буде основою для формування ІК-підтримки наукової діяльності.

Слід відзначити систему EPrints, яка $\epsilon$ найпоширенішою у сфері управління репозитаріями цифрових об'єктів, та є у вільному доступі [9]. Ця система забезпечує створення електронних каталогів бібліотечних фондів та їх повноцінне функціонування і розвиток; підвищує рівень автоматизації бібліотек шляхом використання сучасних ліцензійних програмних продуктів; полегшує створення інтернет-порталу бібліотеки; має можливість використовувати наявне апаратне забезпечення; підтримує формати файлів: HTML, PDF, Postscript, MS PowerPoint, MS Word, JPEG, PNG, GIF, BMP, TIFF, MPEG, QuickTime, AVI. Отже, може бути системою для створення інформаційно- 
комунікаційної підтримки наукової діяльності. Нижче, на рисунку 2, пропонується модель ІК-підтримки наукової діяльності з використанням системи EPrints.

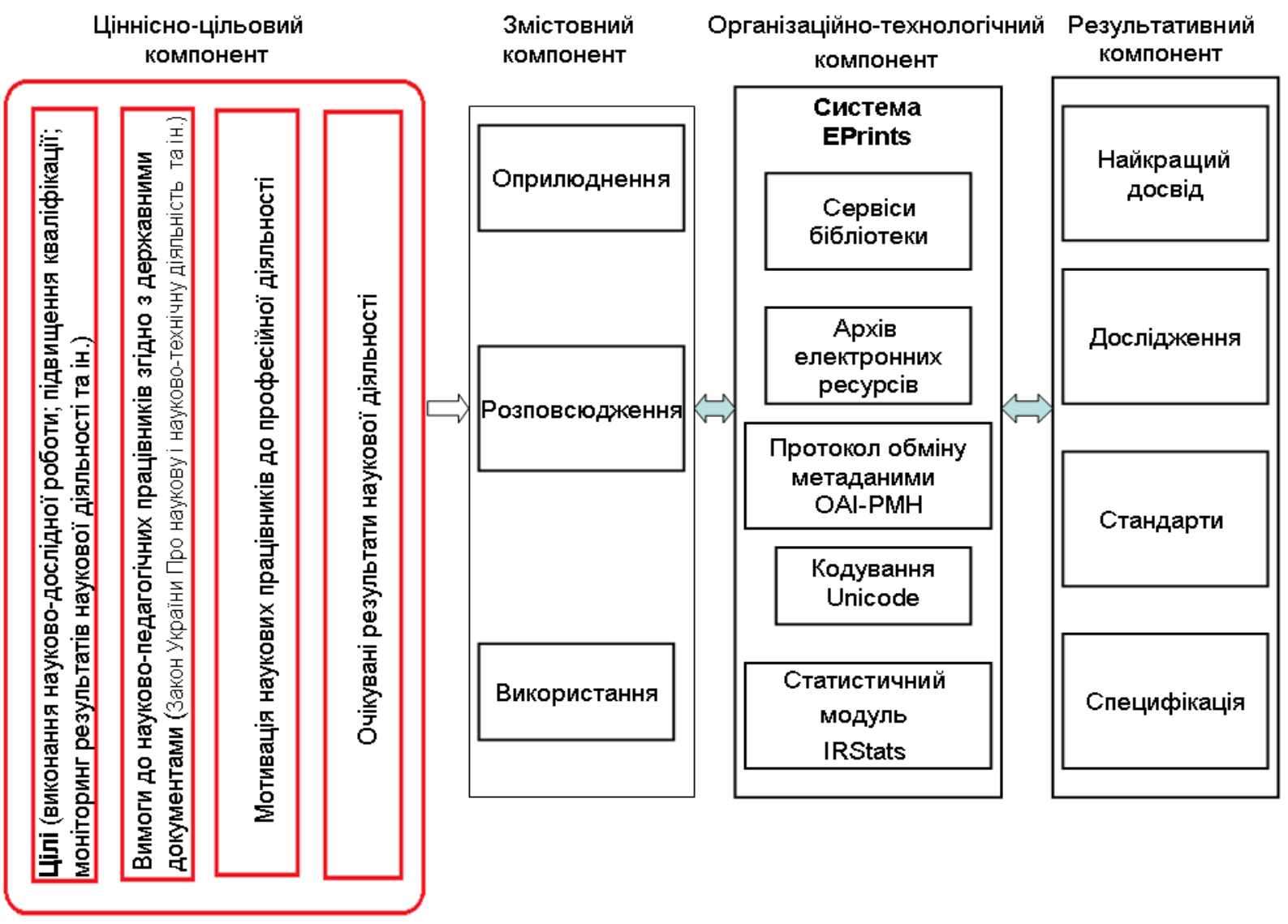

Pис. 2. Модель IK-підтримки наукової діяльності з використанням системи EPrints

Структурними компонентами моделі інформаційно-комунікаційної підтримки наукової діяльності є:

- ціннісно-цільовий, що включає сукупність цілей наукової діяльності згідно 3 вимогами, що прописані у Законі Україні «Про наукову та науково-технічну діяльність» [3], цінностей, які формуються відповідно до вимог сучасного інформаційного суспільства та мотивації до наукової діяльності; результат, запланований відповідно до цілей наукової діяльності, який представлений у науковій продукції;

- змістовний, який включає впровадження результатів наукової діяльності в галузі педагогічних наук та передбачає такі дії як оприлюднення, розповсюдження і використання продукції наукових установ;

- організаційно-технологічний, який представлений складовими системи EPrints, що забезпечують повний набір послуг для впровадження результатів наукової діяльності в галузі педагогічних наук (сервіси бібліотеки, архів електронних ресурсів, протокол ОАI-PMH [12], кодування Unicode, статистичний модуль IRStats);

- результативний, що включає досвід, дослідження відповідно до професійної діяльності наукових працівників, встановлення стандартів наукової діяльності відповідно до іï специфікації (психологічна, педагогічна та ін.).

Про використання результатів наукової діяльності свідчать дані щодо цитування або посилання на таку наукову продукцію як монографії, статті, посібники, збірники 
наукових праць, матеріали конференцій або їх рукописи та ін. у публікаціях наукових співробітників, вчителів та ін., повідомлення (відгуки, рецензії, коментарі, рекомендації та ін.) про таку продукцію, результати експертного опитування, документальне підтвердження впровадження (довідки, акти, листи підтримки, включення до списків рекомендованих джерел) та ін. [8]. Відповідно до визначених вище рамок, що пропонуються для використання результатів наукової діяльності в організаційнотехнологічному компоненті моделі ІК-підтримки наукової діяльності на базі системи EPrints, $є$ такі складові системи, як:

- ті, що забезпечують основні сервіси бібліотеки: захист відомостей та даних, розмежування прав доступу, пошукові інформаційні сервіси [2];

- статистичний модуль IRStats, що надає можливість проводити моніторинг використання результатів наукової діяльності [4];

- кодування Unicode, що дозволяє знаходити науковий матеріал за ключовими словами на будь-якій мові [6];

- створення архівів електронних ресурсів, які можуть об'єднувати файли різних форматів, що надає можливість використовувати різну наукову продукцію [6].

Розповсюдження результатів наукової діяльності стає можливим завдяки відкритим архівам, що створюються у середовищі системи EPrints, яка підтримує протокол обміну метаданими OAI-PMH (Open Archives Initiative - Protocol for Metadata Harvesting) [12], який забезпечує послуги доступу та пошуку. Ініціатива «Відкриті архіви» (OAI, Open Archives Initiative) розробляє та просуває стандарти інтероперабельності з метою ефективного поширення електронних ресурсів, а також підвищення доступності обміну науковими відомостями і даними.

Оприлюднення - це опублікована продукція, що $\epsilon$ результатом наукової діяльності відповідно до наукової дослідної роботи (НДР) та доступ до неї користувачів мережі Інтернет, моніторинг автоматизованих процесів збирання, опрацювання та подання даних про кількісні й якісні характеристики такого публікування. Завдяки системі EPrints стає можливим вільний доступ до наукової продукції різного типу в межах певних колекцій, зокрема за темою НДР, за автором та за автоматично сформованими даними щодо кількості публікацій, наприклад, за роками проведення НДР (рис. 3).

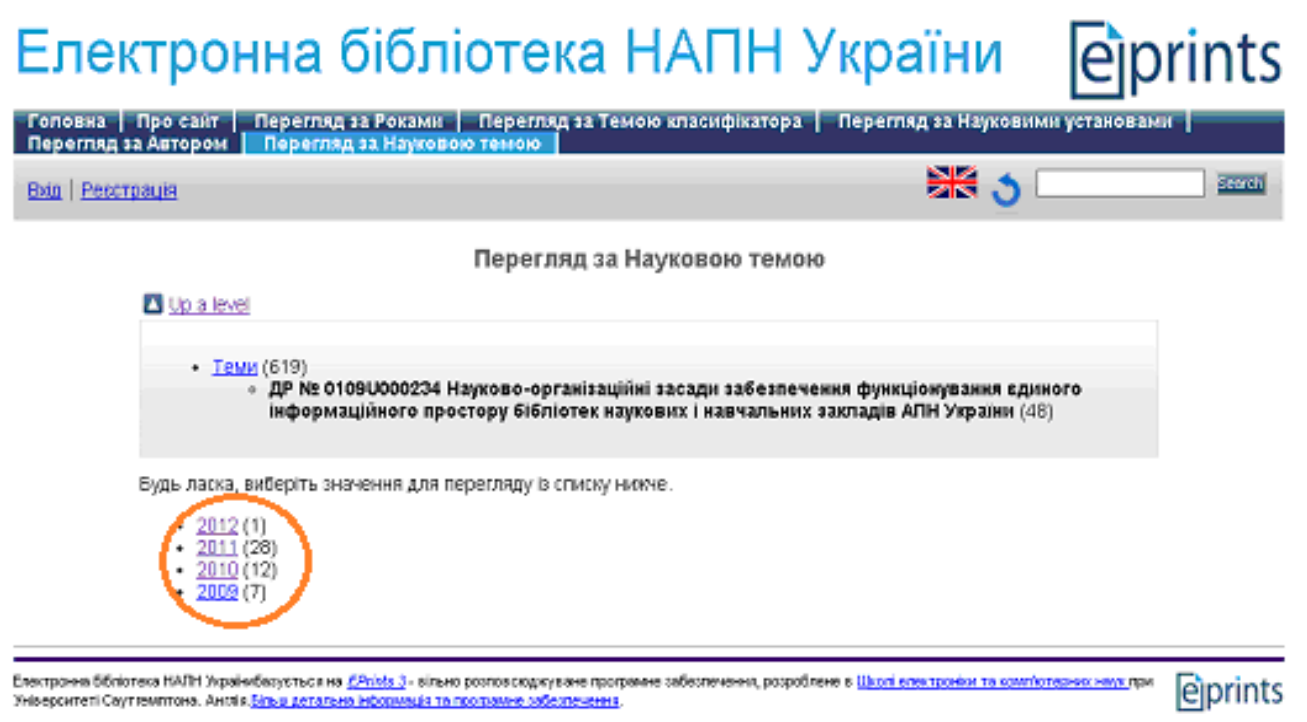

Рис. 3. Перегляд за Науковою темою відповідно за терміном проведення НДР в електронній бібліотеці 
Важливим при оприлюдненні, розповсюдженні та використанні наукової продукції є підтвердження цих дій, яке відбувається за допомогою моніторингу. Таким чином, можна переглянути актуальність будь-якої НДР серед вітчизняних та зарубіжних користувачів, шляхом завантаження відповідних ресурсів з ЕБ. Так, для ЕБ, розроблених у системі EPrints, може використовуватися статистичний модуль IRStats (http://lib.iitta.gov.ua/cgi/irstats.cgi), який дозволяє за будь-який період одержати дані про кількісні та якісні показники завантажень всієї продукції, розподіленої в межах певних колекцій (наукової установи, їі підрозділу, теми класифікатора, автора, теми НДР) або ж завантажень окремої одиниці такої продукції. [10]. Нижче, на рисунку 4, представлений скриншот сторінки IRStats, на якій можна обрати (1) тему НДР, (2) автора, (3) період, за який буде аналізуватися оприлюднення, розповсюдження та використання наукової продукції.

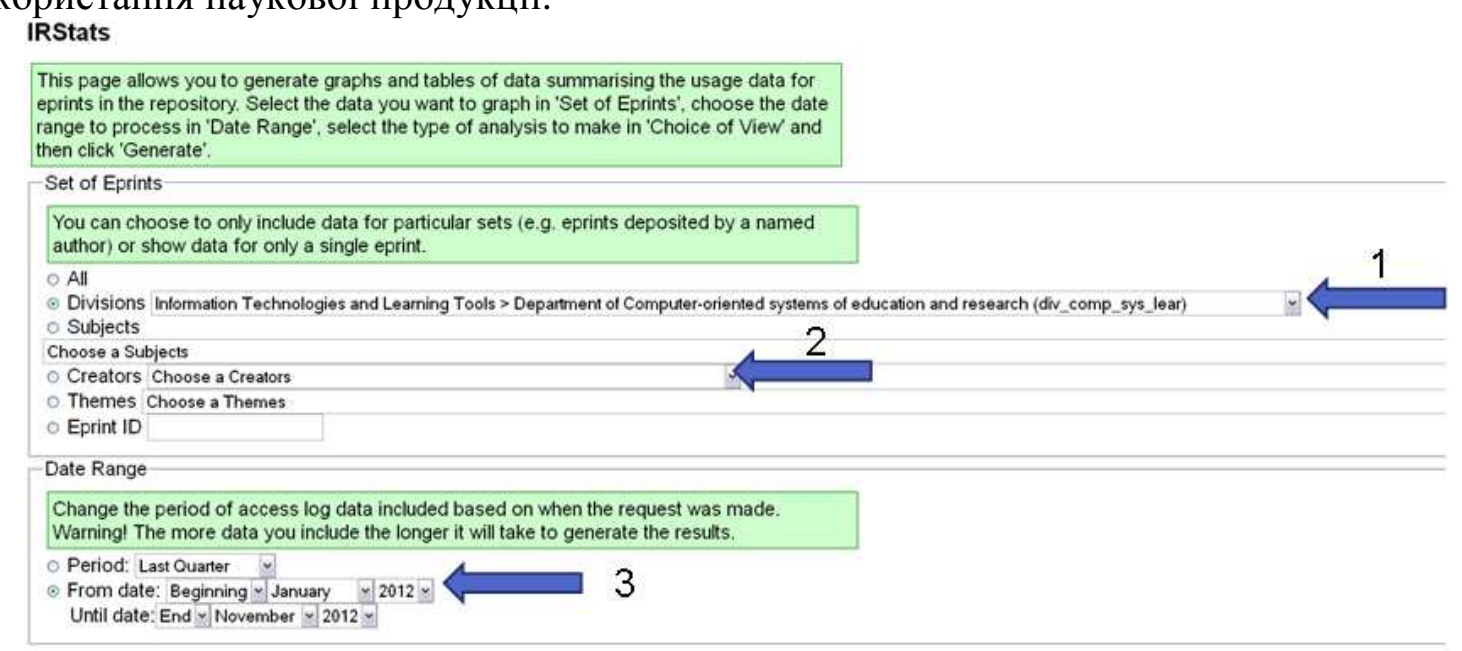

Puc. 4. Фрагмент інтерфейсу модуля IRStats для вибору ресурсів та періоду збору даних про їх завантаження з електронної бібліотеки .

Результати групуються (рис. 5) за такими показниками як, наприклад, «десять найбільш завантажених ресурсів протягом місяця», «десять найбільш популярних авторів» за обраний період та ін.

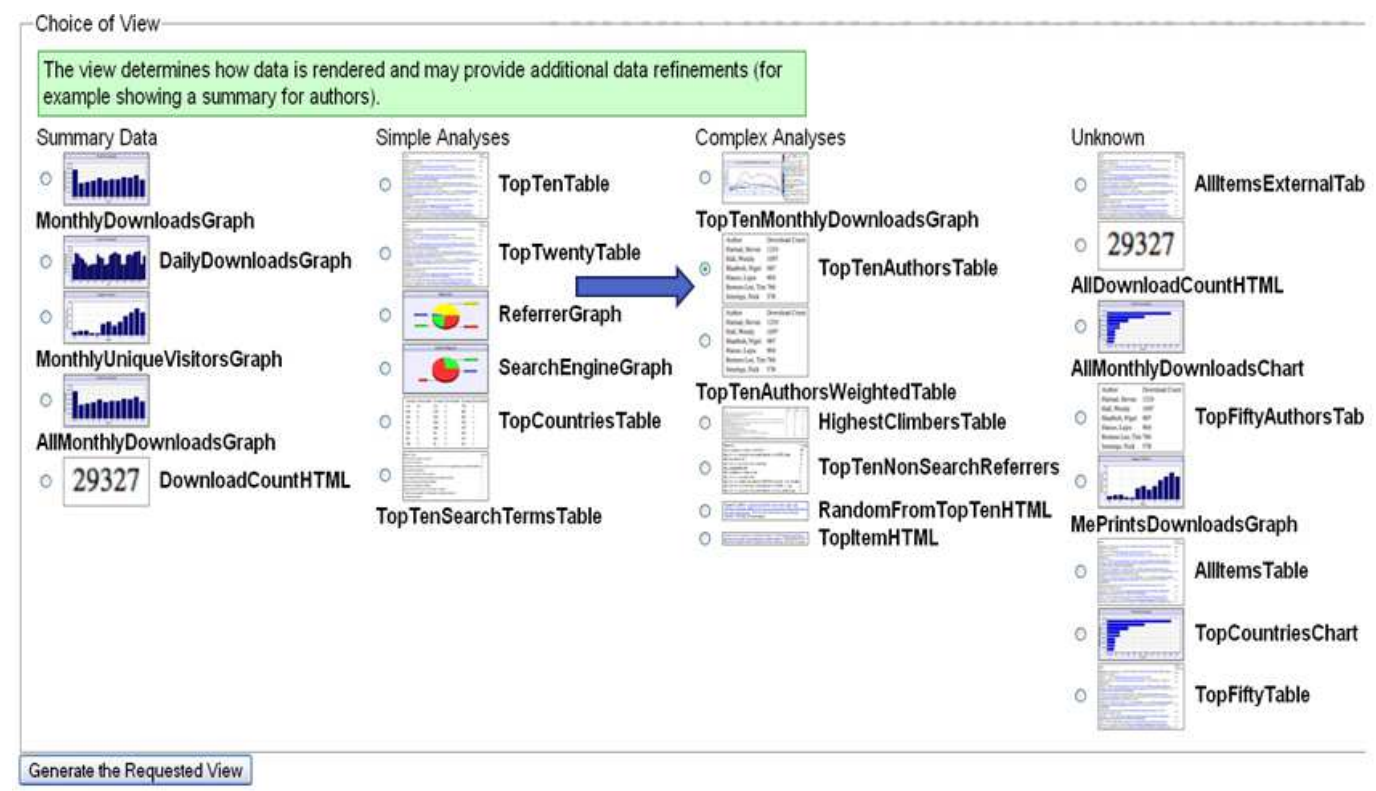

Puc. 5. Фрагмент інтерфейсу модуля IRStats для збору й опрацювання даних про кількісні та якісні показники завантаження ресурсів бібліотеки 
Таким чином, за допомогою статистичного модуля IRStats можна провести достовірний аналіз актуальності наукової продукції, з'ясувати окремі особливості іiі розповсюдження та виконати оперативний зріз використання наукових результатів.

\section{ВИСНОВКИ ТА ПЕРСПЕКТИВИ ПОДАЛЬШИХ ДОСЛІДЖЕНЬ}

У ході проведеного дослідження:

- уточнено поняття «інформаційно-комунікаційна підтримка наукової діяльності», що означає допомогу та сприяння суб'єктам наукової діяльності в отриманні та розповсюдженні наукового результату 3 використанням IKT;

- запропонована модель IK-підтримки наукової діяльності на базі системи EPrints, яка має забезпечити ефективне оприлюднення, розповсюдження і використання наукової продукції.

Відповідно до заявлених компонентів моделі ІК-підтримки наукової діяльності висувається припущення, що використання даної моделі буде сприяти систематизації роботи наукових працівник в постійно зростаючому обсязі при незмінних часових обмеженнях, підтримувати їх мотивацію до підвищення якості наукової продукції.

Підтвердження цього припущення є перспективою подальшого дослідження.

\section{СПИСОК ВИКОРИСТАНИХ ДЖЕРЕЛ}

1. Биков В. Ю. Моделі організаційних систем відкритої освіти: монографія / В. Ю. Биков. - К.: Атіка, 2008. - 684 с.

2. Електронні інформаційні бібліотечні системи наукових i навчальних закладів: монографія [Електронний ресурс] / [Спірін О.М., Іванова С.М., Новицький О.В. та ін.]; за наук. ред. проф. В.Ю. Бикова, О.М. Спіріна. - К.: Педагогічна думка, 2012. - Режим доступу: http://lib.iitta.gov.ua/606

3. Закон України Про наукову і науково-технічну діяльність (Відомості Верховної Ради України (ВВР), 1992, N 12, ст.165) [Електронний ресурс] - Режим доступу: http://zakon2.rada.gov.ua/laws/show/1977-12

4. Кондаков Н. И. Логический словарь-справочник / Н. И. Кондаков. - 2-е изд. - М.: Наука 1975. $-720 \mathrm{c}$.

5. Научно-технический прогресс: словарь / [сост.: В. Г. Горохов, В. Ф. Халипов]. - М.: Политиздат, 1987. - 366 с. 9 , с. 219.

6. Новицкий А.В., Кудим К.А., Резниченко В.А, Проскудина Г.Ю.. Создание научных архивов с помощью системы EPrints [Електронний ресурс] - Режим доступу: http://eprints.isofts.kiev.ua/157/

7. Ожегов С. И. Словарь русского языка / под ред. С. И. Ожегова, Н. Ю. Шведова. - 20-е изд. - М.: Русский язык, 1988. - 750 с.

8. Положення про впровадження результатів науково-дослідних робіт Національною академією педагогічних наук України [затвердж. Постановою Президії НАПН України від 19 травня 2011 року, протокол № 1-7/6-159; зі змінами, затвердж. Постановою Президії НАПН України від 21 червня 2012 року, протокол № 1-7/7-225].

9. Програмне забезпечення Eprints [Електронний ресурс] - Режим доступу: http://www.eprints.org/software/

10. Спірін О.М. Інформаційно-комунікаційні технології моніторингу впровадження результатів науково-дослідних робіт [Електронний ресурс] / О. М. Спірін // Інформаційні технології і засоби навчання - 2013. - 4 (36). 4 - Режим доступу до журн.: http://journal.iitta.gov.ua/index.php/itlt/article/view/890\#.Um0_zlP82aQ.

11. Chowdhury Gobinda. The Role of Digital Libraries in a Time of Global Change: 12th International Conference on Asia-Pacific Digital Libraries, ICADL 2010 Gold Coast, Australia, June 21-25, 2010 Proceedings. Lecture Notes in Computer Science (Vol. 6102). Information Systems and Applications, incl. Internet / Web, and HCI. / Gobinda Chowdhury. - Springer, 2010. - 270 p. 
12. The Open Archives Initiative Protocolfor Metadata Harvesting ProtocolVersion 2.0 of 2002-06-14. [Електронний pecypc] - Режим доступу: http://www.openarchives.org/ $\mathrm{OAI} / 2.0 /$ openarchivesprotocol.htm

Матеріал надійшов до редакиї 17.10.2013 p.

\title{
ПРОЕКТИРОВАНИЕ ИНФОРМАЦИОННО-КОММУНИКАЦИОННОЙ ПОДДЕРЖКИ НАУЧНОЙ ДЕЯТЕЛЬНОСТИ НА БАЗЕ СИСТЕМЫ ЕРRINTS
}

\author{
Иванова Светлана Николаевна \\ заведующая отделом компьютерно ориентированных систем обучения и исследований \\ Институт информационных технологий и средств обучения НАПН Украины, г. Киев, Украина \\ iv-svetlana@yandex.ru
}

\begin{abstract}
Аннотация. Статья посвящена проблеме проектирования модели информационнокоммуникационной поддержки научной деятельности для обеспечения эффективного обнародования, распространения и использования продукции научных учреждений. Уточнено понятие «информационно-коммуникационная поддержка научной деятельности» и предложена структура информационно-коммуникационной поддержки. Создана модель информационно-коммуникационной поддержки научной деятельности на базе системы EPrints. В рамках модели выделены такие компоненты как ценностно-целевой, содержательный, организационно-технологический, результативный. Было выяснено, что использование предложенной модели информационно-коммуникационной поддержки научной деятельности систематизирует работу научных работников в постоянно возрастающем объеме их продукции и поддерживает мотивацию научных работников к повышению ее качества.
\end{abstract}

Ключевые слова: информационно-коммуникационная поддержка научной деятельности; система EPrints; научная продукция.

\section{DESIGN OF INFORMATION AND COMMUNICATION SUPPORT OF SCIENTIFIC RESEARCH ON THE EPRINTS BASIS}

Svitlana M. Ivanova

Head of Computer oriented systems of education and research department Institute of Information Technologies and Learning Tools of NAPS of Ukraine, Kyiv, Ukraine iv-svetlana@yandex.ru

\begin{abstract}
The article deals with the problem of designing a model of information and communication support research activities to provide effective disclosure, dissemination and use of researching product by institutions. It is specified the concept of «information and communication support research activities» and proposed structure of information and communication support. There is proposed the model of information and communication support research activities on the EPrints basis. There is identified components such as value-targeted, informative, organizational, technological, resultative within the model. It was discovered that using the proposed model of information and communication support research activities organizes the work of researchers in the growing volume of scientific production and supports researchers' motivation to increase its quality.
\end{abstract}

Keywords: information and communication support research activities; system EPrints; scientific production.

\section{REFERENCES (TRANSLATED AND TRANSLITERATED}

1. Bykov V. Yu. Organizational models of open education: a monograph: monohrafiya / V. Yu. Bykov. K.: Atika, 2008. - 684 s. (in Ukrainian) 
2. Electronic information systems research libraries and educational institutions: monograph [online] / [Spirin O.M., Ivanova S.M., Novyc"kyj O.V. ta in.]; za nauk. red. prof. V.Yu. Bykova, O.M. Spirina. - K.: Pedahohichna dumka, 2012. - Available from: http://lib.iitta.gov.ua/606 (in Ukrainian)

3. Law of Ukraine on scientific and technical activities (Vidomosti Verxovnoyi Rady Ukrayiny (VVR), 1992, N 12, st.165) [online]. - Available from: http://zakon2.rada.gov.ua/laws/show/1977-12 (in Ukrainian)

4. Kondakov N. I. Logic dictionary catalog / N. I. Kondakov. - 2-e izd. - M.: Nauka 1975. — 720 s. (in Russian)

5. Scientific and technological progress: the dictionary / [sost.: V. G. Gorohov, V. F. Halipov]. - M.: Politizdat, 1987. - 366 s. 9, s. 219. (in Russian)

6. Novickij A.V., Kudim K.A., Reznichenko V.A, Proskudina G.Ju.. Creation of scientific archives using the system EPrints [online]. - Available from: http://eprints.isofts.kiev.ua/157/ (in Russian)

7. Ozhegov S. I. Dictionary of Russian language / pod red. S. I. Ozhegova, N. Ju. Shvedova. — 20-e izd. M.: Russkij jazyk, 1988. - 750 s. (in Russian)

8. Regulation on the implementation of the results of research by the National Academy of Pedagogical Sciences of Ukraine [approved by. Decree of the Presidium of the Academy of Pedagogical Sciences of Ukraine of 19 May 2011, Protocol № 1-7/6-159; amended, approved. Decree of the Presidium of the Academy of Pedagogical Sciences of Ukraine of June 21, 2012, report № 1-7/7-225]. (in Ukrainian)

9. Software Eprints [online]. - Available from: http://www.eprints.org/software/(in Ukrainian)

10. Spirin O.M. ICT monitoring of researches results implementation [online] / O. M. Spirin // Informacijni texnolohiyi i zasoby navchannya - 2013. - 4 (36). - Available from: http://journal.iitta.gov.ua/index.php/itlt/article/view/890\#.Um0_zlP82aQ.(in Ukrainian)

11. Chowdhury Gobinda. The Role of Digital Libraries in a Time of Global Change: 12th International Conference on Asia-Pacific Digital Libraries, ICADL 2010 Gold Coast, Australia, June 21-25, 2010 Proceedings. Lecture Notes in Computer Science (Vol. 6102). Information Systems and Applications, incl. Internet / Web, and HCI. / Gobinda Chowdhury. - Springer, 2010. - 270 p. (in English)

12. The Open Archives Initiative Protocolfor Metadata Harvesting ProtocolVersion 2.0 of 2002-06-14. [online]. - Available from: http://www.openarchives.org/ OAI/2.0/openarchivesprotocol.htm (in English) 